\title{
Factors of land abandonment in mountainous Mediterranean areas: the case of Montenegrin settlements
}

\author{
Annelies Kerckhof ${ }^{1}$, Velibor Spalevic ${ }^{2}$, Veerle Van Eetvelde ${ }^{1}$ and Jan Nyssen ${ }^{{ }^{*}}$
}

\begin{abstract}
Land use changes have been investigated in the surroundings of 14 rural Montenegrin settlements in order to get specific information about trends in land abandonment since around 1950. Permanently, seasonally and less inhabited settlements with different geographic conditions were studied. This was done by interviewing local inhabitants, which enabled a holistic approach to reveal the underlying processes of land abandonment. According to the observed patterns of land use change, the study sites can be categorized into intensified, urbanized, extensified, overgrown and forested cases. The category of extensified settlements is characterized by a highly reduced agricultural management intensity, resulting in an increase in grasslands and fruit trees at the expense of cropland. This land use change is mainly related to emigrating and aging inhabitants, having less livestock. Such extensive land use is found in both permanently inhabited and abandoned villages. Only some studied settlements became largely overgrown by bushes and forest. The steep average slope gradients and a large distance to the nearest city are explanatory factors of such land abandonment. Land use intensification takes place in low-lying areas located nearby towns.
\end{abstract}

Keywords: Montenegro, Land use changes, Marginal farmlands, Oral history, Qualitative research, Urbanization

\section{Background}

A dominant trend of abandonment, reforestation and extensification has been found in the mountainous European areas since 1950, in line with predominant socioeconomic changes through the continent (Mottet et al. 2006; Jepsen et al. 2015). The combination of environmental, economic and social aspects act as a driver for migration in rural contexts and it influences the land use changes (Kranjc 2008). More specifically, industrialization and urbanization have altered the landscape patterns since the Second World War, due to shifts in lifestyles, resulting in extensification of remote and physically disadvantaged rural areas and intensification and agricultural modernization of more urban areas (Antrop 2005; Klijn and Vos 2000). Especially rural, mountainous landscapes are determined as vulnerable to land abandonment (Baldock et al. 1996). Decrease or abandonment

\footnotetext{
*Correspondence: jan.nyssen@ugent.be

1 Department of Geography, Ghent University, Ghent, Belgium Full list of author information is available at the end of the article
}

of ancient farming systems has caused an overgrowth of traditional farmlands by shrubs and trees (MacDonald et al. 2000). Such patterns have been registered in the mountainous regions of Southern Slovenia, where the traditional agricultural landscape was overgrown by forest by 1980 . Relations of this trend to socio-economic factors have already been revealed: the emigration of rural inhabitants during the twentieth century and the accessibility of suitable lands to dwellings was detected as a driver of local agricultural intensification. Afterwards, some villages near access roads increased in terms of inhabitants but-as their activities are not related to agriculture anymore-this did not result in recent land use changes (Pausic and Carni 2012).

Traditional landscapes have been evolving gradually over time and were characterized by appropriate land use according to the local physical circumstances (Antrop 2000; Renes 2015). Initial settlements have often been established, taking into account land qualities and natural resources (LaGro 2001) as these provide inhabitants with ecosystem services on which they could rely for survival 
and welfare. According to Fagerholm et al. (2012), ecosystem services can be both materialistic (proper conditions for various crops or livestock, firewood, construction wood, wild fruits, herbs, etc.) as non-materialistic (places for enjoying nature, recreation, etc.). Inhabitants often possessed patches of land at different locations to have various physical circumstances (Antrop 2000) and a system of transhumance, where people seasonally migrated with their livestock in order to use grasslands in the mountains (Dodgshon and Olsson 2007). The human impact on the landscape visually occurs as lynchets, created by soil accumulated at the edges of parcels due to the long-lasting ploughing of croplands on slopes (Chartin et al. 2011), and forest cutting and picking of stones caused land to become sensitive to soil erosion, especially on hill slopes. When such human impacts diminish, the erosion degree reduces as forested, bushy and even grassy areas fix the soil and land resilience might take place (Nyssen et al. 2014). However, karst zones prove to be vulnerable to land degradation because they recover badly from degradation (Calo and Parise 2006).

Little scientific research has been performed concerning land abandonment factors within Montenegro. As this mountainous region is characterized by a variety of physical environmental settings and recently went through some turbulent socio-economic developments, it is able to indicate an interesting pattern of recent changes in land use and cover. Local-scale sites comprising different physical and demographic characteristics have been studied to obtain specific information about land abandonment. A holistic approach has been adopted as nowadays, many study methodologies are based on the integration of biophysical, environmental factors and socio-economic evolution to increase the understanding of landscape dynamics (Mottet et al. 2006).

\section{Methods}

\section{Study area}

\section{Physical environment}

Montenegro is situated in Southeast Europe along the Adriatic Sea and within the Dinaric Alps, a Western Balkan mountain range comprising mainly NW-SE oriented ridges (Kranjc 2008). The small $\left(13,812 \mathrm{~km}^{2}\right)$ country can be divided in seven geomorphological regions (Frankl et al. 2016; Fig. 1). The narrow coastal zone mainly contains small beaches with steep limestone slopes rising to average heights of $800 \mathrm{~m}$, a ria coast centered on Boka Kotorska and a large debris cone near Albania on which sand beaches developed (Nyssen et al. 2014). NE of this zone lies the high karst zone: a dry Cretaceous limestone plateau characterized by karst phenomena, where the only fertile lands occur in poljes. This region is incised by the inland depression, which extends about $60 \mathrm{~km}$ in
NW-SE direction (Mugoša 2008). It is mainly filled with Quaternary materials and comprises the polje of Nikšić, the area around the meandering river Zeta, the capital Podgorica, the lowland of Zeta Plain and Skadar Lake. Parallel with this zone the elevated Durmitor Flysch region is situated (often higher than $2000 \mathrm{~m}$ ) with a relatively soft lithology dominated by sandstones, siltstones, marls and conglomerates. Furthermore, the Prokletije contains a varied geology (of schists, sand- and limestone, dolomites, volcanic outcrops, ...) with glacial geomorphic features. The highest parts of this mountainous region extend to Kosovo and especially Albania. Within Montenegro, the Northwestern Highlands contain most peaks (with Bobotov Kuk being the highest: $2523 \mathrm{~m}$ a.s.l.) and plateaus. This region mainly contains limestone, its geomorphology is determined by a combination of glacial and karst processes (Annys et al. 2014). In the north, the Tara canyon marks the border with the Northern crystalline hills, which covers a large part of the country along the NE border and it mainly comprises flysch and sandstone sediments: softer materials forming an undulating landscape.

The climate of the coastal and high karst zone is Mediterranean with hot, dry summers and mild, wet winters (Nyssen et al. 2014) but precipitation is also affected by the mountain massifs (Kranjc 2008). The limestone hinterland is covered with typical bushy Mediterranean vegetation as maquis, garrigue and degraded evergreen woodland (Foster-Turley et al. 2010). The inland depression contains large rectangular vineyards (Zeta Plain) and some swampy areas (around Skadar Lake) and can be extremely hot during summer. The northern regions have a continental climate with rainfall, which is more equally distributed over the year, cold winters and warm summers. Forests and pastures cover large parts of these regions (Nyssen et al. 2014).

\section{History and demography}

Montenegro is characterized by a turbulent history. After hard times during the Second World War, the Socialist Federal Republic of Yugoslavia (SFRY) was reorganized in six republics: Bosnia and Herzegovina, Croatia, Macedonia, Montenegro, Serbia and Slovenia (Pittaway 2004). Industrialization occurred, causing migration to towns, urbanization and abandonment of mountain farming practices (MacDonald et al. 2000). After 1953, the short-lived Yugoslav agricultural collectivization faded away and gradually, farmers shifted from subsistenceto market-based production during the 1960s (Pittaway 2004). Then, industries of aluminum, steel and energy also became highly important as the transport infrastructure was growing (Miller 2005). In the early 1990s, the economic reformation towards an open market failed 


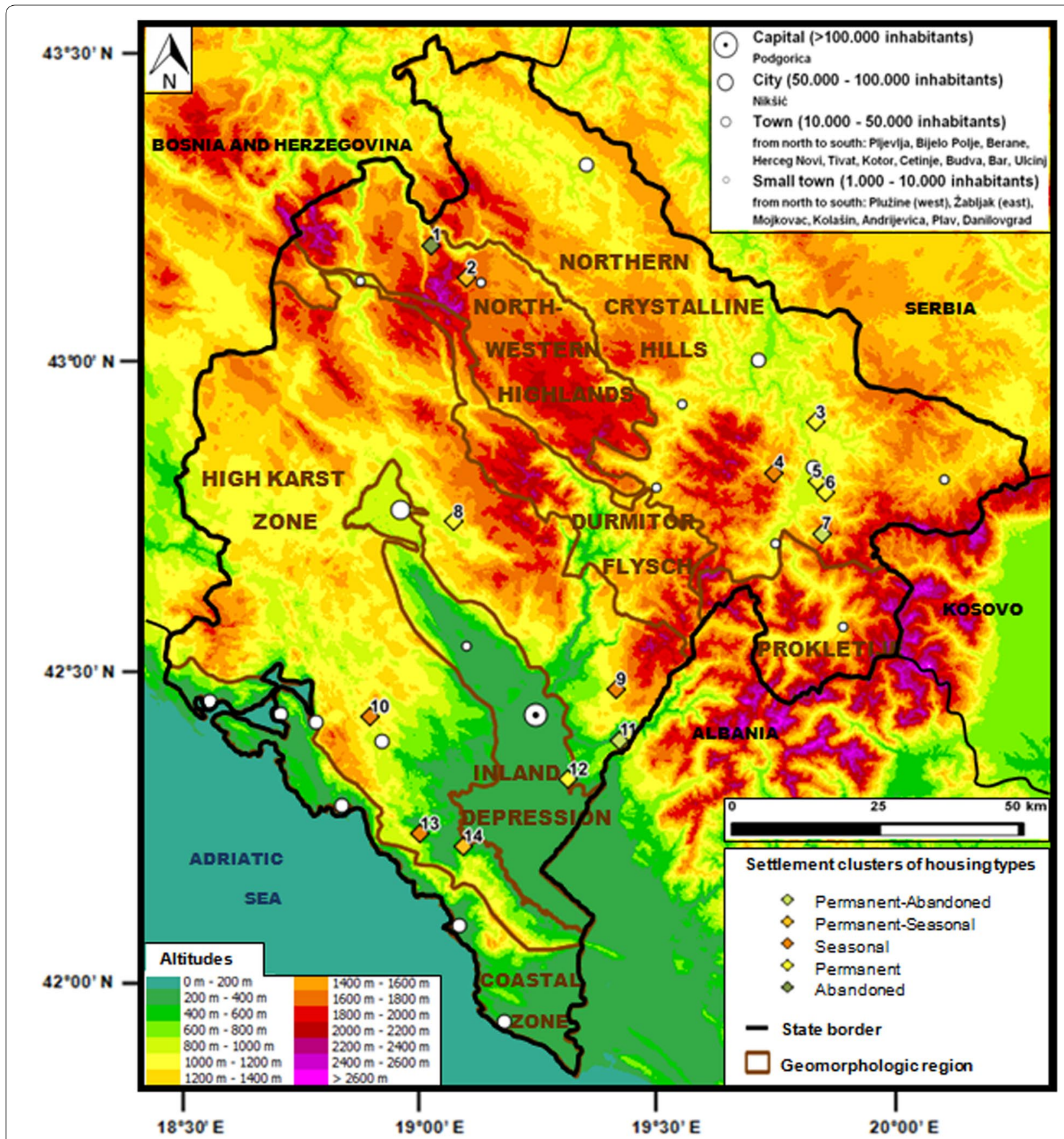

Fig. 1 Selected settlements by cluster of housing type situated within distinct geomorphologic regions and with a range of altitudes and distances to the nearest town. Source geomorphic regions by Frankl et al. (2016)

and as a result, a large decline in the Yugoslav economy took place (Lazic and Sekelj 1997). Then, the SFRY disintegrated (but Serbia and Montenegro temporarily stayed the last two members in the Federal Republic of Yugoslavia), defining the 1990s as the decade of Yugoslav wars (Miller 2005). Although Montenegro was located outside of the war zone, its general development suffered a lot.
In 2006, the country became independent after a referendum that was narrowly won due to the Albanian minority (Pond 2006), but Montenegro (especially the north(east) ern part) remained strongly linked to Serbia (MONSTAT 2011a, b).

A strong population growth marked the twentieth century in Montenegro: from 311,000 inhabitants in 1921 
to 620,000 at the beginning of the twenty-first century (MONSTAT 2011a, b). However, many internal migrations took place since around 1950, with a continuous emigration trend from the northern regions. The ratio of $46 \%$ of the urban Montenegrins living in the northern regions in 1961 declined to about $30 \%$ in 2000 (Mugoša 2008). Urbanization occurred in all 21 municipalities (due to migration, to their central settlement and mainly to Podgorica) (MONSTAT 2011a, b). Montenegro has 1256 settlements, 40 of which are urban. The coastal municipalities have the densest network of settlements, which have been analyzed for the presence of cultural and historical elements and forms of agricultural patterns (Curovic and Popovic 2014); especially the central area is economically important and highly urbanized, as the two largest cities (Podgorica and Nikšić, containing about one third of the population) are located there (MONSTAT 2011a, b).

\section{Land use changes}

Around 1900, Montenegro mainly consisted of bare land (Kranjc 2008), as only about $35 \%$ of its landscape was densely vegetated. The coastal and central zones were especially barren (for about half of their area), while not even one tenth of the northern zone was barren wasteland, as it had more forests, meadows (respectively almost 30 and $40 \%$ ) and farmland (as opposed to small poljes and dry fields in the other areas). During the twentieth century, especially between 1950 and 1980, the Montenegrin landscape showed an overall increase in vegetation. The share of barren lands in the coastal and central zones strongly decreased in favor of shrubland and forests, while there was less vegetation growth in the northern zone, where forests grew at the expense of farmland, which halved at least (Nyssen et al. 2014). This evolution runs parallel with large sectorial shifts in employment, as the Montenegrins working in agriculture (about $75 \%$ in 1948) fell back to $5 \%$ in 1981 (Radović 1981). Restitution of lands to owners has also been playing a role in the decline of agriculture since the end of the 1980s (Mugoša 2008). However, due to the economic crisis in the 1990s, some marginal lands have been temporarily cultivated again (Grimes et al. 2005). Since 2000, areas occupied by infrastructure-often related to tourism-have rapidly increased in all Montenegrin regions (Nyssen et al. 2014) and regrowth of vegetation has accelerated. In 2008, dense forests covered $45 \%$ of the country and another $9 \%$ was under other woody vegetation types (including bushes, brushwood, maquis and stone steppes). By 2012, this had increased to respectively about 60 and $10 \%$, making Montenegro one of the most forested countries in Europe (Andelić et al. 2012).

\section{Selection of local-scale study sites}

A variety of settlements in terms of demographic and physical characteristics has been selected to investigate land abandonment in relation to human lifestyles and their environment. Therefore, data about housing types per settlement (MONSTAT 2011a, b) were used; all dwellings have been categorized as permanently/ seasonally occupied or abandoned. The share of housing types within a settlement defines it as permanent, permanent-seasonal, seasonal, abandoned or permanentabandoned. A cluster analysis was carried out in SPSS so as to categorize 941 of all 1305 Montenegrin settlements in these five distinctive clusters. Settlements with more than 1000 houses, less than 10 houses and more than $25 \%$ undetermined utilization types were excluded from the analysis. Besides representing a variety of settlement types, the selected settlements should be located in several of the geomorphological regions described by Frankl et al. (2016). Eventually, 14 settlements were chosen as study sites (Fig. 1; Table 1) representing all settlement types and four geomorphological regions (mainly the high karst zone and northern crystalline hills and-to a lesser extent-the northwestern highlands and inland depression).

\section{Conducting and processing interviews}

Semi-structured interviews have been conducted to gather first-hand information about land use/cover changes and thus land abandonment over time. The used questionnaire comprised six main topics: the basic characteristics of interviewees, agricultural situation and ecosystem services (both nowadays as in the past), aspects of land cover/use change (including matters as vegetation overgrowth and changes in the agricultural system, landscape and infrastructure), some physical geographical processes (like climate change and erosion), personal view and migration. Specific defined questions such as "How much livestock do you have now?" were not aimed at obtaining exact quantitative data but at facilitating answers and getting an idea about magnitudes. The questions ranged from completely open-ended to more narrow (although still open-ended). Participants were not forced to stick to the sequence of questions to prevent interruptions of their narratives. The used approach offers space to both theoretical ideas and empirical findings: the structure ensures the discussion of preconceived topics, while interviewees still have latitude to bring new aspects to the study (Galletta 2013). Interviewees were considered experts of their environment (Fagerholm et al. 2012) and the way of interviewing them provoked 'oral histories' (stories about specific memories related to the landscape), which 


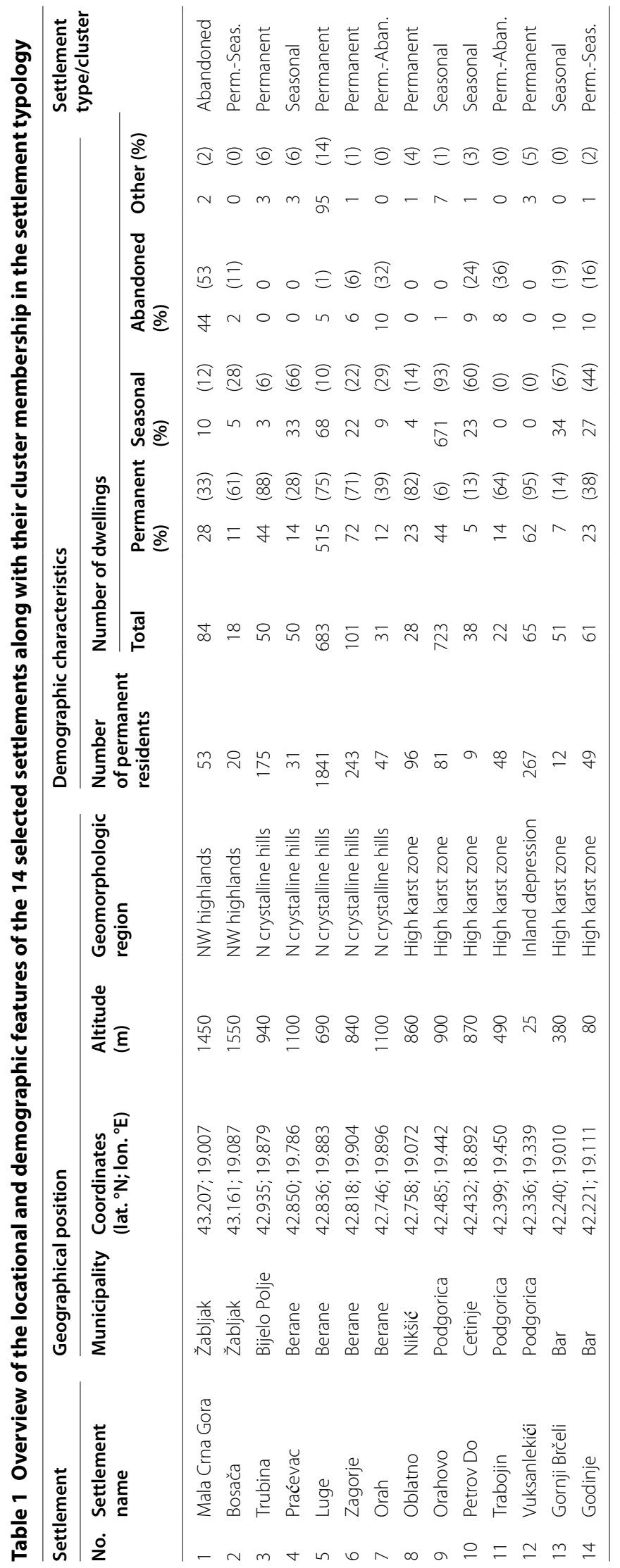


helped to notice key periods of change, motivations, meanings and lifestyles (Galletta 2013). When possible, walks with informants were carried out to let them show interesting phenomena on the field (Fig. 2). Two to five interviews have been executed per settlement, until major study questions were answered (Neuman 2003). In total, 40 different (individual or group) interviews have been undertaken. As knowledge about landscape changes through recent history was required, mainly elderly people have been interviewed; approximately $70 \%$ was older than 60 years.

All interviews were recorded, transcribed and loaded into the qualitative data analysis program NVivo to structure all data and to implement a constant comparison. This was done by using an open coding approach as included in the grounded theory procedures (Strauss and Corbin 1998). This means that relevant interview quotes were marked with codes of themes derived from literature as having a relation with land abandonment (Leech and Onwuegbuzie 2007). Afterwards, relations between coded quotes were explored by bringing them together per category and settlement in order to investigate the indicators of land abandonment.

\section{Quantification of the environmental characteristics}

To examine the impact of the altitude, slope gradient, previous woody vegetation cover and distance to the nearest town, these environmental features were quantified. For the altitude, the elevation of the residential core of the village was taken. The slope gradient was measured by the creation of paths with height profiles on four transects (in N-S, NE-SW, E-W and NW-SE directions) through each study site (until the surrounding hill slopes) on recent satellite images of Google Earth. Subsequently, the sum of the absolute height differences in each transect was divided by its length to calculate the average slope gradient. Next, the woody vegetation cover was quantified using a point-counting method (Bellhouse 1981). This included the placement of a $(10 \times 10)$ regular grid (with $100 \mathrm{~m}$ between neighboring intersections) over Yugoslav topographic maps of the 1970s (on a scale of 1:25,000) of the settlement areas. For all intersections,
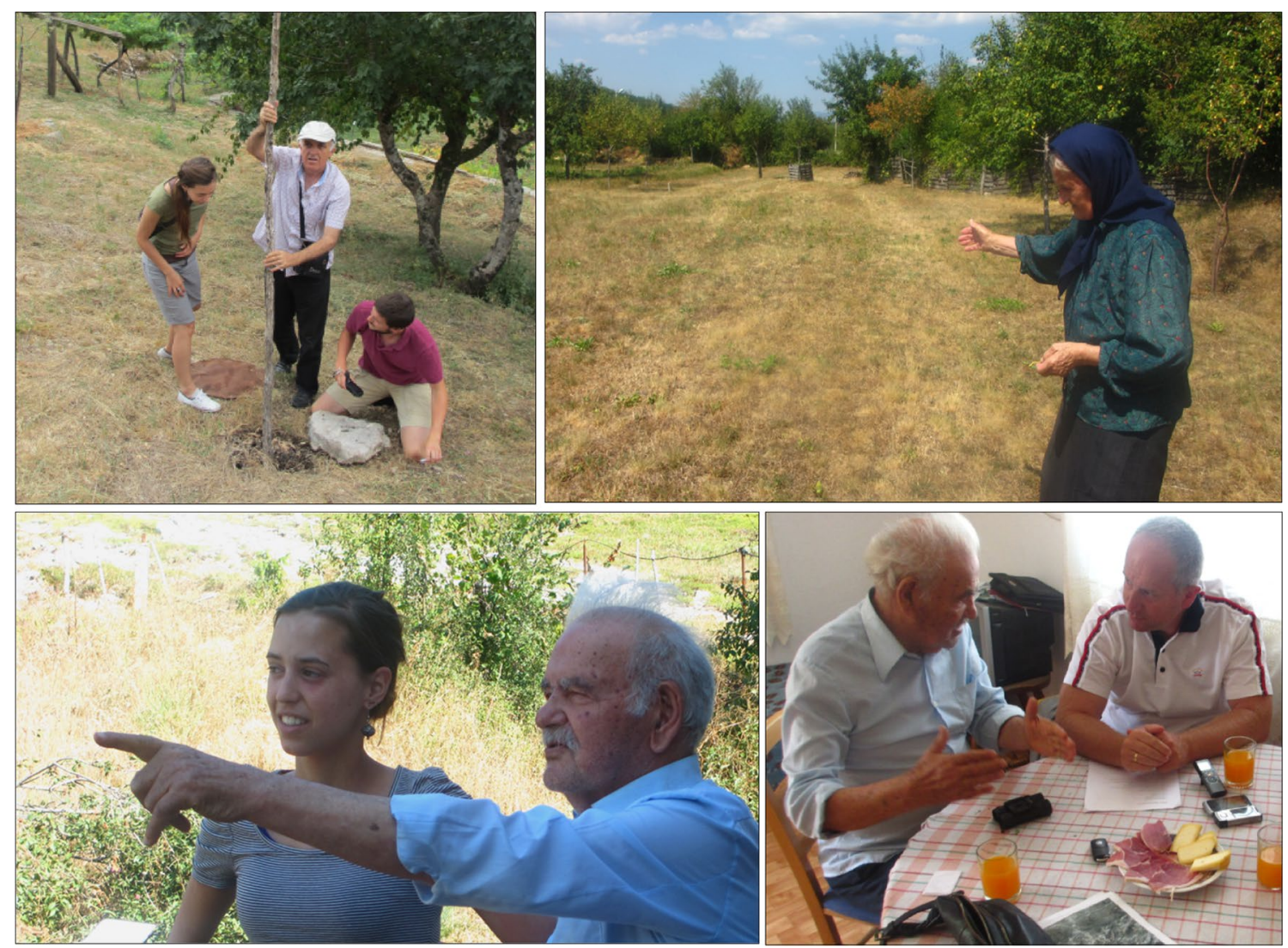

Fig. 2 Participants as key informants of their own settlement area. a Interviewee showing a karst phenomenom on his property, Orahovo, 10/08/2013. b Interviewee showing her earlier cultivated area, Oblatno, 13/08/2013. c Interviewee showing the forest around his house, Petrov Do, 14/08/2013. d The typical informal setting for the conduction of interviews, Petrov Do, 14/08/2013 
it was recorded whether they corresponded with woody vegetation or not. Eventually, a percentage of woody vegetation cover was obtained for each study site. Lastly, the shortest distance to the nearest city (mostly the municipal capital) by road was measured in Google Earth.

\section{Rating the evolution of landscape elements and statistical analysis}

From all collected data, quantitative values could be determined for the evolution of several landscape elements during the last few decades. These landscape elements have been classified into six categories: constructions (houses, barns, roads, etc.), cultivation (cropland, vineyards, gardens, etc.), grasslands (meadows and pastures), areas covered by fruit trees, bushy areas and forests. Measures for these parameters were scored on a bilateral scale, with -2.5 and 2.5 as respectively a large decrease and increase in the concerned factor and 0 , meaning no change. This expert rating was done for each settlement using the interview transcripts, maps, satellite images and field observations. Afterwards, these values were used to create clusters with a similar change in land use/cover-settlement profiles-by cluster analysis. Finally, Pearson correlations between the quantified environmental factors and the measures of landscape changes (including trends of intensive and extensive land use and natural vegetation, comprising the summed scores of respectively the categories constructions and cultivation, grasslands, fruit trees and bushy area and forest), were calculated to explore their relations. Also, coefficients between these environmental factors were taken so as to check their mutual relations. Regression analyses have been carried out when conditions were met.

\section{Results}

Environmental characteristics and agricultural components

The selected settlements show a variety in altitude, slope gradient, previous woody vegetation cover and distance to the nearest town (Table 2). Furthermore, some concepts typical for rural Montenegrin areas emerged from the interviews. Firstly, the katun was mentioned, a complex of mountain pastures with extensive common meadows (and often cottages), where inhabitants lived during summertime with their livestock. Some settlements had several katuns, located at different altitudes, which were used in sequence. Nowadays, many of them are not used anymore and became (partly) abandoned. Also, lynchets, nowadays mainly under grassland, prove the previous existence of croplands on slopes (Fig. 3). Cultivation in dolines was encountered in study sites on limestone but nowadays, these only subsist as small gardens. The production of lime and charcoal was traditionally performed in calcareous regions with a degraded forest but has almost been abandoned.

\section{Trends in the settlement areas}

While comparing all interview transcripts, several predominant aspects have been detected. About $80 \%$ of the interviewees mentioned farming as a (former) secondary job and $10 \%$ as their main employment. Most of them are still cultivating vegetables and fruits for personal use. The number of livestock has strongly decreased (for almost everyone) since 50 or even 2 years earlier; nowadays most inhabitants have none to three cows, some have about 10-30 sheep but almost no one still owns a horse or ox. About $70 \%$ of the interviewees stated a large

Table 2 Geographic parameters altitude, average slope gradient, woody vegetation cover in the 1970s and distance to nearest town for each settlement

\begin{tabular}{|c|c|c|c|c|c|}
\hline No. & Settlement name & Altitude (m) & $\begin{array}{l}\text { Average slope } \\
\text { gradient (\%) }\end{array}$ & $\begin{array}{l}\text { Woody vegetation } \\
\text { cover in the 1970s (\%) }\end{array}$ & $\begin{array}{l}\text { Distance to nearest } \\
\text { town }(\mathbf{k m})\end{array}$ \\
\hline 1 & Mala Crna Gora & 1450 & 10.0 & 5 & 18 \\
\hline 2 & Bosača & 1550 & 13.5 & 56 & 5 \\
\hline 3 & Trubina & 940 & 13.0 & 64 & 16 \\
\hline 4 & Praćevac & 1100 & 27.5 & 56 & 12 \\
\hline 5 & Luge & 690 & 8.0 & 25 & 2 \\
\hline 6 & Zagorje & 840 & 16.5 & 45 & 7 \\
\hline 7 & Orah & 1100 & 26.0 & 43 & 17 \\
\hline 8 & Oblatno & 860 & 12.0 & 57 & 12 \\
\hline 9 & Orahovo & 900 & 14.5 & 26 & 21 \\
\hline 10 & Petrov Do & 870 & 8.5 & 27 & 14 \\
\hline 11 & Trabojin & 490 & 21.5 & 62 & 25 \\
\hline 12 & Vuksanlekići & 25 & 8.0 & 7 & 12 \\
\hline 13 & Gornji Brčeli & 380 & 22.5 & 55 & 25 \\
\hline 14 & Godinje & 80 & 22.0 & 43 & 25 \\
\hline
\end{tabular}




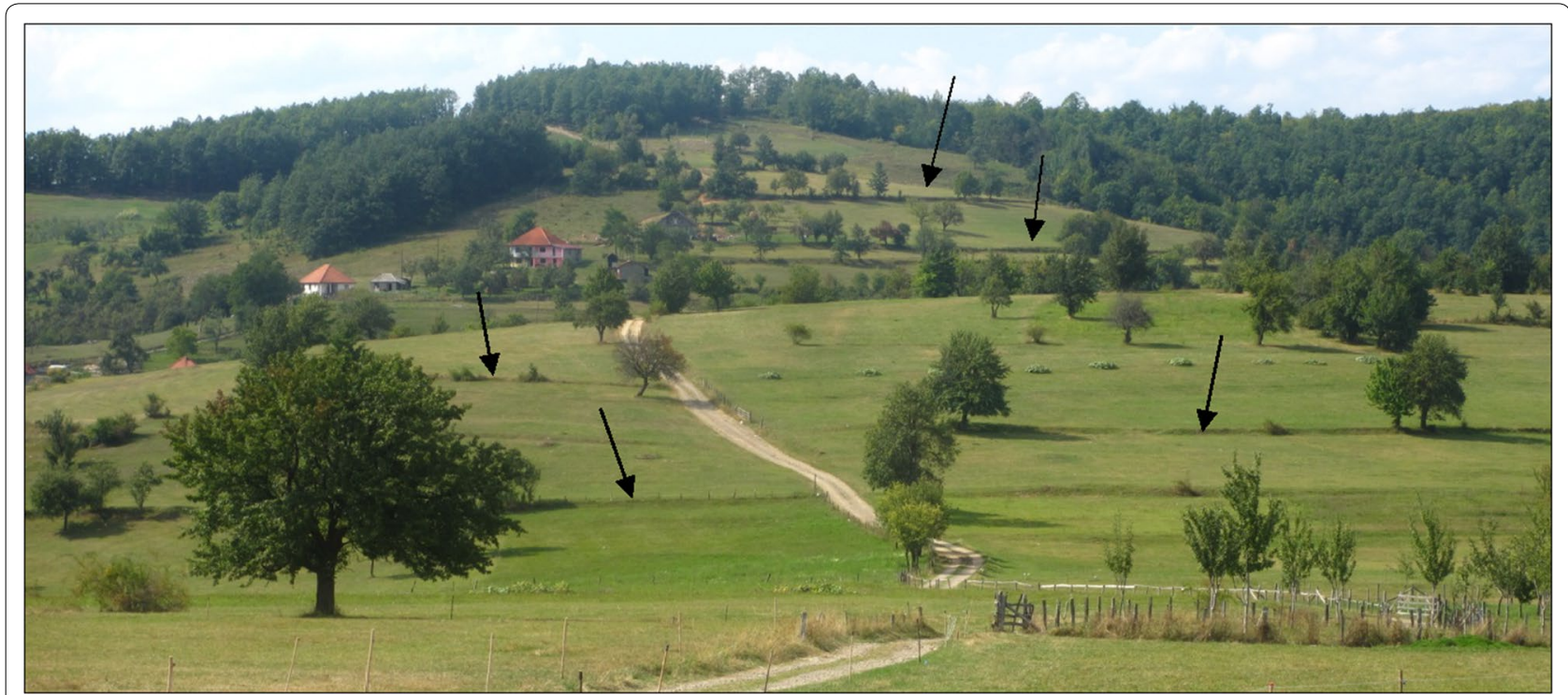

Fig. 3 Sklads or lynchets on the grasslands of the settlement Trubina. Several sklads are marked by an arrow. 01/09/2013

difference in territorial use: a more extensive instead of intensive land use with less cropland, more (maintained) grasslands and fruit trees or more overgrown bushy areas. Most interviewees go to town less than five times a month to visit shops, banks and doctors, as their settlements do not have these facilities. Almost all interviewees mentioned getting a (small) pension from the state or from the country where they had worked temporarily. More than $90 \%$ of the children of the interviewees had migrated to an urban area; about half of them moved abroad and the other half to the Montenegrin cities. Almost all participants told they preferred living in their settlement over an urban lifestyle. Besides, many of them said that it is easier to farm and live rurally than before but less people (especially youngsters) want this. Furthermore, in all studied villages, inhabitants own lands with different kinds of land cover; (almost) each one has a garden around the house, meadows on different altitudes and one or more plots of forest. A diminished soil quality (due to a decrease in livestock) has also frequently been mentioned. Furthermore, many interviewees stated that the summers became hotter and drier than before. Also, the inflations of the 1990s caused no large changes or problems in rural settlements, as inhabitants were relatively self-sufficient. Specific features and trends for settlements are given in Table 3.

\section{Land abandonment factors and processes Location}

The distance to urban areas influences the land use change. Large cities (as Podgorica) have a larger sphere of influence than smaller towns (as Žabljak). Urbanrural gradients of study sites include Luge, Zagorje (both permanent), Praćevac (seasonal) and Orah (permanent-abandoned) to the city Berane, Bosača (permanent-seasonal) and Mala Crna Gora (abandoned) to the town Žabljak and Vusanlekići (permanent) and Trabojin (permanent-abandoned) to Podgorica. Generally, the closer a village is situated to a town, the less abandoned it became. Within permanent(-seasonal) inhabited study sites (as Trubina and Bosača), abandoned and overgrown grasslands are generally situated at the edges of the village, because parts of the land had been exchanged between staying and migrating family members. However, when settlements became more abandoned (as Mala Crna Gora), overgrown areas appear on their territories everywhere.

\section{Physical geography}

The altitude determines the presence of katuns and thereby land abandonment, as these elevated areas often were abandoned first. For example, the katuns of Praćevac are at the first level partially (Fig. 4) and at the second level, totally abandoned and overgrown. Furthermore, the often mentioned hotter, dryer and longer summers cause more dry soils nowadays. In parts of the Montenegrin karst region, water has always been the main restriction for agriculture as cultivable soil is very scarce and thus all small fertile grounds (dolines) were (and still are) well maintained (as in Petrov Do, Fig. 5). Other areas (as Godinje and Gornji Brčeli) have springs and more fertile soils, which became quickly overgrown 
Table 3 Statements emerged from the interviews about several situations in the studied settlement areas, with + as confirmation, - as negation, / as not determined or relevant and the numbers 1-14 representing the settlements (see Tables 1, 2)

\begin{tabular}{|c|c|c|c|c|c|c|c|c|c|c|c|c|c|c|}
\hline \multirow[t]{2}{*}{ Statement } & \multicolumn{14}{|c|}{ Settlement number } \\
\hline & 1 & 2 & 3 & 4 & 5 & 6 & 7 & 8 & 9 & 10 & 11 & 12 & 13 & 14 \\
\hline Land is mainly used for grass cutting instead of crops & / & + & + & + & + & + & + & + & + & / & + & - & - & - \\
\hline Most fields are abandoned and overgrown by bushes & + & - & - & + & - & - & + & - & - & - & - & - & + & + \\
\hline The katuns in the mountains are still used nowadays & + & / & + & - & + & + & - & - & - & / & - & / & - & - \\
\hline Now there are more forested areas around the village & + & + & + & - & + & + & + & - & - & + & - & - & + & + \\
\hline ... because people cut less trees now & + & + & - & - & + & + & + & + & - & + & + & + & + & + \\
\hline There is more forest but of less quality now than before & / & - & + & + & - & + & - & + & + & / & / & - & - & - \\
\hline There is more degraded forest now due to forest fires & - & - & - & + & - & - & - & + & + & + & + & + & - & - \\
\hline There are high quality trees for construction wood & + & + & - & + & + & + & + & - & - & - & - & - & - & - \\
\hline Residents still collect mushrooms or berries in the forest & + & + & + & + & + & + & + & + & - & - & - & - & + & + \\
\hline Residents made kreč or charcoal with degraded wood & - & - & - & - & + & - & - & + & + & + & + & + & + & + \\
\hline Now there are more (fruit) trees in the village & / & / & + & + & + & + & + & + & + & / & + & - & + & + \\
\hline There are erosion processes & - & - & - & - & + & - & + & + & + & + & + & + & + & - \\
\hline There are karst phenomena & + & + & - & - & - & - & - & - & + & + & + & - & + & - \\
\hline People cleaned farmlands of stones and made walls of it & + & - & - & - & - & - & - & + & + & + & + & - & + & + \\
\hline There are terraces & - & - & - & - & - & - & - & - & + & + & + & - & + & + \\
\hline There are lynchets & - & - & + & + & + & + & + & + & - & - & - & - & - & - \\
\hline It is still difficult to survive due to the lack of water & + & - & + & - & - & - & - & - & - & + & + & - & - & - \\
\hline Residents built (a part of) their roads or electricity & + & - & / & / & - & - & + & - & - & + & / & - & + & - \\
\hline Residents still burn their garbage or throw it in the river & + & + & + & + & - & - & + & + & - & + & + & - & - & - \\
\hline There is a pro-Serbian mentality in the settlement & - & - & - & + & + & + & + & + & + & / & - & - & - & - \\
\hline The main emigrations were in the 1970 s & - & + & - & + & / & + & + & + & + & + & + & + & + & + \\
\hline The main emigrations were in the 1990s & + & - & + & - & / & - & + & + & - & - & - & + & - & - \\
\hline Now only the elderly people remain to live here & + & - & - & + & - & - & + & + & + & + & + & - & + & + \\
\hline Only a few families live here during the winter & + & - & - & + & - & + & - & - & - & + & - & - & + & + \\
\hline
\end{tabular}

due to bad maintenance and abandonment. Usually, the best grounds are being kept, while less fertile lands had been abandoned or exchanged. In Bosača, the latter was done with lands in Pitomine (a neighbouring village), which have a lower soil quality. Also, the slope gradient influences the land abandonment. In several villages, interviewees told that abandoned and overgrown lands are mainly situated on steep slopes, while these areas were traditionally meant for grasslands (rather than croplands).

\section{Vegetation and ecosystem services}

Several study sites have forests with high quality trees (mainly pines) which have value as timber and therefore, inhabitants do not ruin them by making charcoal or lime, which was done in regions with a degraded, bushy vegetation. Some interviewees own separate forest patches with trees for firewood (lower situated) and high quality trees (located higher). People always need permission and tax payment for logging. Generally, all settlements are more vegetated now; mainly the areas around the houses became greener because of an increase in fruit trees, grasslands and bushy areas at the expense of croplands. Therefore, most settlements gained a more closed landscape without attributing this to abandonment alone. In Zagorje, the central plain traditionally comprised open space but during the 1980s, new houses appeared with an increase in gardens and plum trees. The study sites Gornji Brčeli and Godinje show many new bushes and trees due to the abandonment of croplands on cultivation terraces, leading to an almost inaccessible vegetated area. A result of the emerging forest is the increased amount of mushrooms, berries and herbs in these settlements, enabling more inhabitants to collect and sell them.

\section{Agriculture}

Nowadays, physical circumstances of territories are less determinative than before, as agricultural tools and inputs have drastically improved and local inhabitants do not need much space for farming anymore. Some interviewees mentioned people respected their land more in the past by using the unfertile areas for building 


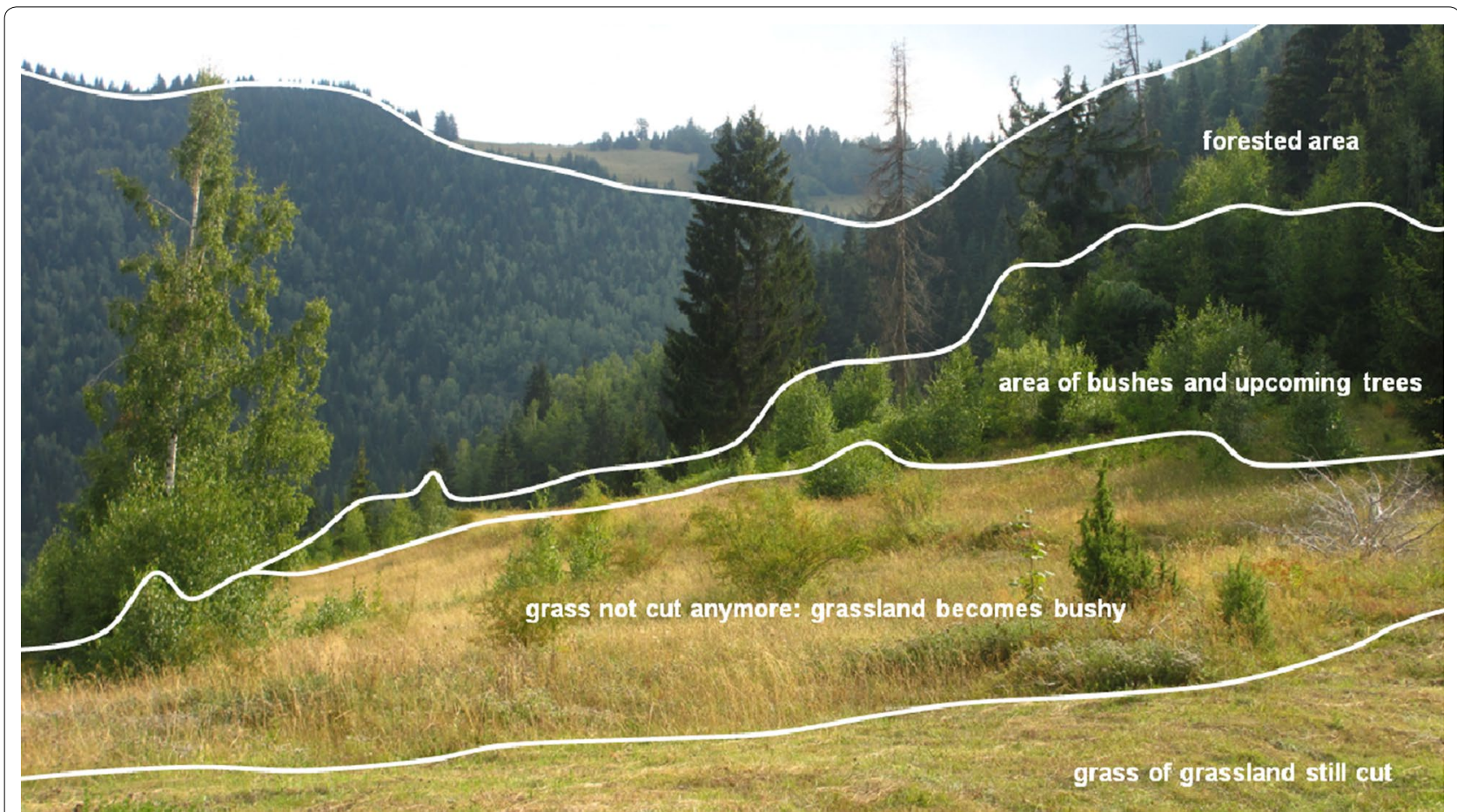

Fig. 4 Phases in the process of overgrowth of grasslands to natural vegetation in the katun Ravni, as not all lands become abandoned at the same time, Praćevac, 02/09/2013

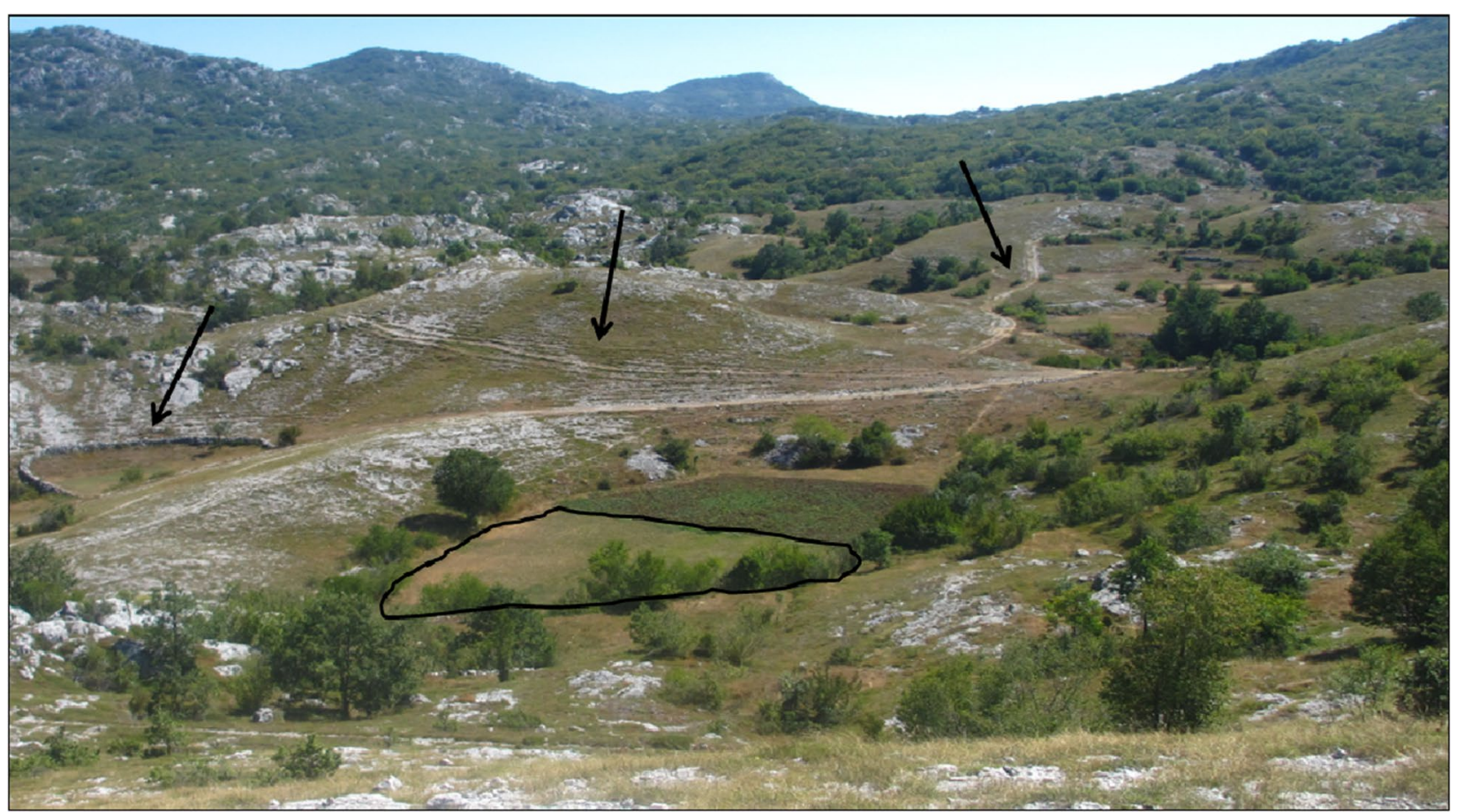

Fig. 5 Half cultivated garden in a doline (foreground). Livestock is still kept in this landscape, as evidenced by the presence of tracks and a pen (arrows). Petrov Do, 14/08/2013 
and keeping fertile grounds for cultivation. For example, the settlement structure of Zagorje evolved from houses only being located at the surrounding hill slopes to the scattered habitat over the territory; also after the devastating earthquake of 1979 in Godinje, a part of its traditional houses on the hill slopes have been rebuilt on the lower, flatter area used for vineyards earlier on. Furthermore, in the past, almost every house had one or two oxen for land cultivation. Herds of sheep, goats or cows were taken to meadows around the village or the katuns. Also, interviewees in Godinje mentioned the former occurrence of stubble grazing on the residues of the harvested croplands. Nowadays, mainly gardens around houses remain areas of intensive land use. Croplands for fodder are no longer necessary, as inhabitants do not have much livestock anymore. A transition from croplands to grasslands, bushy areas and eventually forests is generally observed. However, not all grasslands became overgrown, as several inhabitants were able to maintain them.

\section{Demography}

Demographic changes due to emigration and aging appeared to be the major driving forces for land use change. Most family sizes reduced as many people in their twenties migrated to the cities (mainly their municipal capital, Podgorica or a coastal city) or abroad (often Serbia and some to another ex-Yugoslav country), while the old, remaining family members were passing away. Usually, these remaining persons only cultivate according to their needs and thus, as a result, gardens became smaller. Their old age and the absence of helpers also determine the declining amounts in livestock and crops. One of the reasons for emigration nowadays is that young people cannot find a partner if they stay in their village, as many traditional settlements only house few different families. Furthermore, it was frequently heard that inhabitants temporarily migrated to other nearby countries (mainly Germany, Austria or Italy) to work some time for a higher salary. With less people, less land is cultivated or maintained, more areas become overgrown and less trees are cut for firewood in the forests surrounding the villages. Large variations occur between properties of seasonal inhabitants. Owners are often there during summers, weekends or vacations and they maintain their lands well, while others almost never come, have much overgrown land or let neighbours maintain it.

\section{Society}

Lastly, policy and laws have an impact on the land use change. The establishment of national parks largely influenced the forest policy in the concerned areas.
For example, due to the more strict laws of the Durmitor National Park since the 1980s, the surroundings of Mala Crna Gora became more forested. In several areas which are unprotected as a national park, the laws on tree cutting also became stricter according to interviewees. Since the last 20 years, the authorities have been acting stricter and did not allow firewood cutting for sale; permissions to cut trees in private forests are harder to obtain and there is much forest owned by the state. However, interviewees of some settlements (like Orahovo, near Podgorica) mentioned that nowadays, authorities are tolerating the illegal cutting of good quality forest (facilitated by better machinery, including second-hand military vehicles), which did not happen until 1990. Furthermore, war periods and economic crises had an impact on the environment. The inflation during the 1990s, coupled with weakness of authority, caused more mushroom picking in forests and tree cutting as people needed to be more self-sufficient. Then, there were -about one third- less trees in Bosača, due to the uncontrolled cutting. The collective agricultural system of the early 1950s, when people had to give away their lands, is partly responsible for the many overgrown terrains in Godinje, as these unclaimed lands remain state property until the hypothetical previous owners are claiming them back.

\section{Settlement profiles of landscape changes}

The evolution in land use change of all 14 study sites can be clustered into five distinctive groups of land use change (Fig. 6; Table 4). The first two settlement profile types-urbanized and intensified-both contain only one settlement-respectively Luge and Vuksanlekići. Luge is characterized by an obvious increase in construction but not in cultivation, while Vuksanlekići largely increased in cultivation and -to a much smaller extent- in construction. All other settlements are characterized by a decrease in intensive land use, while most of them show an increase in extensive land use. Seven settlementsBosača, Trubina, Praćevac, Zagorje, Oblatno, Orahovo and Trabojin-are categorized as extensified and characterized by a significant decrease in intensive land use (mainly in terms of croplands) on the one hand and a strong increase in extensive land use (as grasslands and fruit trees) on the other hand. Moreover, they contain recently grown shrubs, bushes and trees. The overgrown settlement profile includes Mala Crna Gora, Orah and Petrov Do and their territories, where intensive land use has strongly decreased but also (slightly) extensive land use (fruit trees and mainly meadows). Furthermore, some surfaces have recently become overgrown by natural vegetation. Finally, Gornji Brčeli and Godinje were heavily forested during the last decades. These settlements 


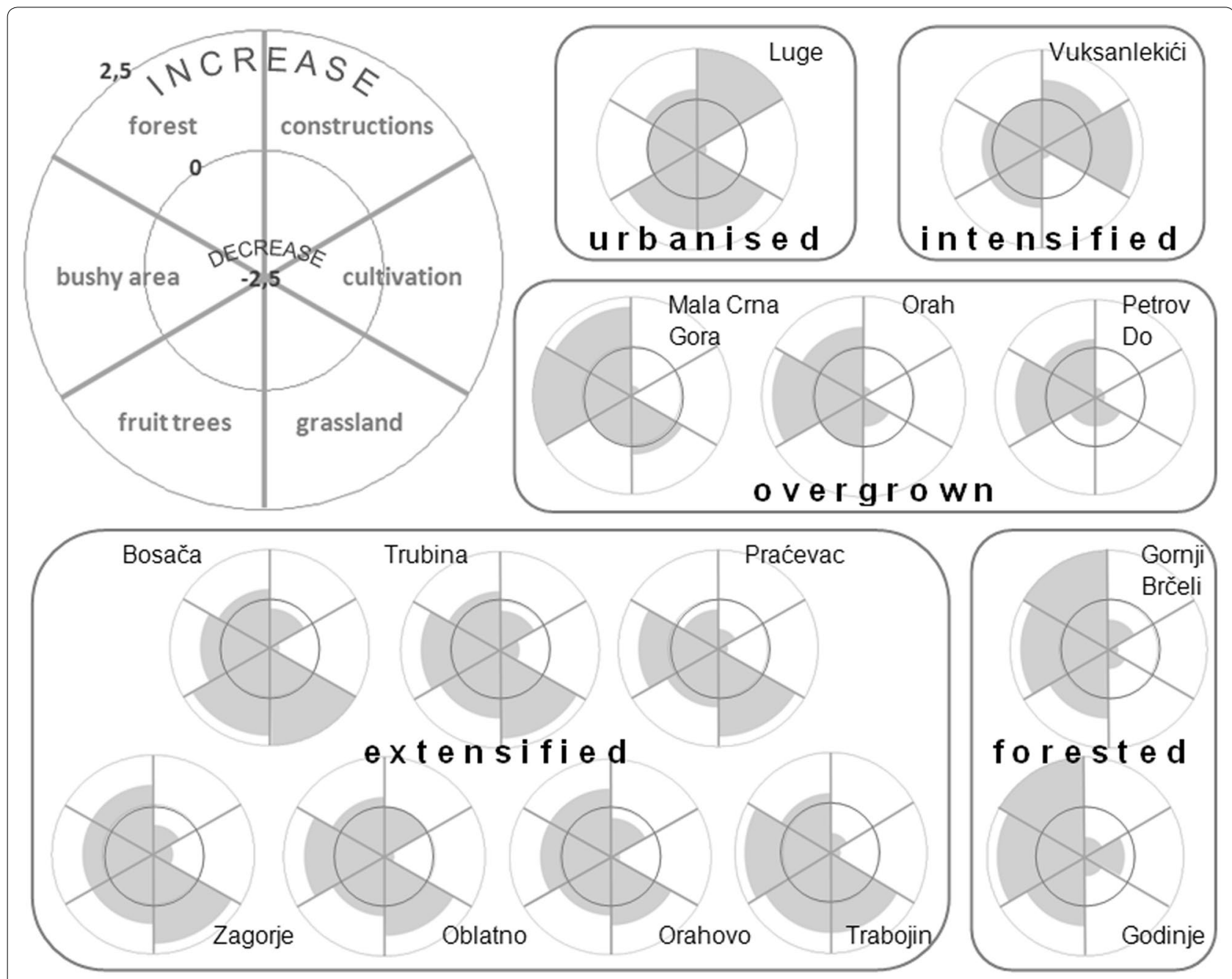

Fig. 6 Pie radar charts showing settlement profiles of land use changes

Table 4 Settlement profiles with a short description of the most important trends

\begin{tabular}{|c|c|c|}
\hline Cluster name & Settlements & Description \\
\hline Urbanised & Luge & $\begin{array}{l}\text { Much more houses, more small gardens and fruit trees, much less } \\
\text { cropland }\end{array}$ \\
\hline Intensified & Vuksanlekići & Much more vineyards, some more houses, much less grassland \\
\hline Extensified & $\begin{array}{l}\text { Bosača-Trubina_Praćevac-Zagorje- } \\
\text { Oblatno-Orahovo-Trabojin }\end{array}$ & $\begin{array}{l}\text { Little less number of houses, often with smaller gardens, much less } \\
\text { cropland, more meadows and fruit trees }\end{array}$ \\
\hline Overgrown & Mala Crna Gora_-Orah_Petrov Do & $\begin{array}{l}\text { Much less houses and cultivation, more bushy areas, some more } \\
\text { forest }\end{array}$ \\
\hline Forested & Gornji Brčeli-Godinje & $\begin{array}{l}\text { Less houses and cultivation, less grass land, much more bushy area } \\
\text { and especially recent forest }\end{array}$ \\
\hline
\end{tabular}

have a decreased area of intensively used land, as well as grasslands.

\section{Comparison of the variables}

According to the calculated Pearson correlation coefficients, the average slope gradient is moderately related to the previous woody vegetation cover $(\mathrm{r}=+0.57)$ and weakly to the distance to the nearest town $(r=+0.47)$. The factor 'altitude' is weakly related to the distance to town $(\mathrm{r}=-0.38)$. Furthermore, correlations between the geographic features and land use changes are investigated, where the former aspects are expected to explain 
Table 5 Matrix comprising Pearson correlation coefficients of possible determining geographical variables (rows) and influenced variables of land use changes (columns)

\begin{tabular}{|c|c|c|c|c|c|c|c|c|c|}
\hline \multirow{2}{*}{$\begin{array}{l}\text { Independent } \\
\text { variables: } \\
\text { geo-graphic aspects }\end{array}$} & \multicolumn{9}{|c|}{ Dependent variables: land use changes } \\
\hline & Construction & Cultvation & $\begin{array}{l}\text { Intensive } \\
\text { land use }\end{array}$ & Grassland & $\begin{array}{l}\text { Fruit } \\
\text { trees }\end{array}$ & $\begin{array}{l}\text { Extensive } \\
\text { land use }\end{array}$ & $\begin{array}{l}\text { Bushy } \\
\text { area }\end{array}$ & Forest & $\begin{array}{l}\text { Natural } \\
\text { vegetation }\end{array}$ \\
\hline Altitude (m) & $-\underline{0.28}$ & $-\underline{0.73} \underline{3}^{* *}$ & $-\underline{0.60} \underline{\underline{*}}^{* *}$ & $\underline{0.40}$ & $-\underline{0.19}$ & $\underline{0.24}$ & $\underline{0.18}$ & $-\underline{0.08}$ & $\underline{0.04}$ \\
\hline Slope gradient (\%) & $-\underline{0.50^{*}}$ & -0.26 & $-\underline{0.47^{*}}$ & 0.11 & $\underline{0.25}$ & $\underline{0.17}$ & $\underline{0.71}^{* * *}$ & $\underline{0.42}$ & $\underline{0.62} \underline{2}^{* *}$ \\
\hline Vegetation (\%) & $-\underline{0.27}$ & $-\underline{0.35}$ & $-\underline{0.37}$ & $\underline{0.54}^{* *}$ & $\underline{0.37}$ & $\underline{0.55}^{* *}$ & 0.23 & $\underline{0.13}$ & $\underline{0.20}$ \\
\hline Distance $(\mathrm{km})$ & $-\underline{0.55^{* *}}$ & 0.04 & -0.32 & $-\underline{0.36}$ & $-\underline{0.28}$ & $-\underline{0.38}$ & $\underline{0.69}^{* * *}$ & $\underline{0.34}$ & $\underline{0.56}^{* *}$ \\
\hline
\end{tabular}

A underline font shows that conditions for linear regression analysis are satisfied, while an italic font shows that this is not the case. The asterisks show the significances of the executed linear regression analyses, with ${ }^{*} p<0.10 ;{ }^{* *} p<0.05,{ }^{* * *} p<0.01$

some values of the latter (Table 5). The strongest correlations are detected between the altitude and changes in the cultivated area $(\mathrm{r}=-0.73)$, slope gradient and changes in the bushy area $(r=+0.71)$ and distance to the nearest town and changes in the bushy area $(r=+0.69)$. The change in the constructed area is significantly correlated with the distance to town $(\mathrm{r}=-0.55)$, as well as the slope gradient $(\mathrm{r}=-0.50)$. The changes in forest and extensive land use appear to be rather unrelated to the studied geographical aspects, with only a moderate correlation $(\mathrm{r}=+0.54)$ between the previous vegetation cover and the change into grassland.

Lastly, when combining all settlement clusters and profiles, a large variation in housing type (settlement clusters) exists for the extensified settlement profiles, having mainly permanent and seasonal settlements. The overgrown settlements are mainly (partly) abandoned and the two forested settlements are seasonal and permanent-seasonal.

\section{Discussion}

\section{Land use changes}

The studied areas show similar trends, as well as variations concerning the land use change. All rural inhabitants still own differently located territories, but while in the past the purpose was to enable several types of land use (Antrop 2000), now less strong relations between land use and soil qualities exist due to the declining cultivation activities. However, cultivating in dolines and maintaining them in the limestone areas (i.e. using their ecosystem services) is still occurring when there is a need for it. In Montenegro, firewood remains the dominant type of fuel for heating, especially in (northern) rural settlements and about $14 \%$ of the households get firewood from their own forest (Glavonjic and Krajnc 2013). Furthermore, lynchets situated in the meadows and terraces overgrown by bushes indicate the decrease of former agricultural practices and the shift in land cover. The land use changes were found to be highly related to the shifts in lifestyles as mentioned by Fry (2000) with social, economic and political driving forces. However, ambiguities exist about the role of the authorities in logging. Some interviewees mentioned more logging in the forests around their village in the early 2000s than before, due to the better machinery and a lack of control. Conversely, in other settlements, interviewees talked about the current stricter laws to cut trees in their own forests and thus the (forced) decrease of it. A possible explanation for this are the stricter laws in the private forests-which significantly increased during the last decades to about $33 \%$ in 2008 (Andelić et al. 2012) - against the inefficient forest management of the state forests (Grimes et al. 2005). However, the forest management became more efficient in controlling the illegally obtained timber wood through clear cuts and wildfires since 2000 according to Foster-Turley et al. (2010). Furthermore, the conclusion of Nyssen et al. (2014) about the general increase of the forest in Montenegro throughout the twentieth century can be more nuanced according to this research. In some sites, it was said that-although there is more vegetation now-the quality of the forest has decreased. Also, many interviewees mentioned that-mainly inside their settlement-the vegetation increased at locations where they cultivated the land before, creating a more closed local landscape. Research in other topographically complex areas (such as the Alps) found that the cultivated land in particular is affected by large socio-economic changes (Schirpke et al. 2012).

\section{Land abandonment versus extensification}

The most frequently observed phenomenon was the decrease of (intensively) cultivated areas and the increase of (extensively) maintained grasslands and fruit trees. Since most inhabitants have less livestock now, they do not need crops for fodder anymore to feed them efficiently. Therefore, a less intensive method is achieved by giving hay through grass cutting on former croplands. As two cows need lots of hay, large meadows have to be maintained. Also, several inhabitants maintain their grasslands only in order to keep their property tidy. 
Because of the aging of the remaining rural inhabitants, it is not evident for them to do intensive labour anymore. Therefore, fruit trees became popular too, as this represents also a more extensive way of gardening. These findings are comparable with the dominant trend of extensification in the mountainous rural European areas since about 1950 (Mottet et al. 2006). The single significant relation between the increasing grasslands and the woody vegetation cover in the 1970 s can be partially explained through the good soil characteristics for vegetation and the intermediate effect of the slope gradient. Land abandonment in terms of an enormous increase in natural, wild vegetation was found to a lesser extent, although in all extensified villages several parcels became so. The overgrown territories turned out to be mainly influenced by their location (far from a city), slope gradient (steep) and altitude (elevated) and have the most abandoned houses. The forested territories are influenced by the same geographical factors but are situated not so high and house more inhabitants that are seasonal.

\section{Interview methods}

Interviewing local inhabitants provided us with useful, detailed data about their lifestyles and habits in particular. However, sometimes contradictory comments were given, so interviews had to be analyzed critically. Indications for reliability were the recurring similar answers by several interviewees of the same settlement. It was easier to ask interviewees detailed questions about their personal experiences than about general landscape evolutions. Also, it was more interesting to interview men, since married women had migrated to the village of their husband and they did not know the area since childhood as a result.

\section{Conclusion}

The evolution of land abandonment in rural Montenegro since about 1950 at 14 local study sites and their underlying processes has been examined. Certain trends can be partially explained through geographical conditions. Settlements with steep slope gradients and large distances to cities show an increase in overgrown, bushy lands, while the cultivated area decreased for villages at high altitudes, and small distances to cities led to more house construction. Also, demographic and social circumstances demonstrated their impact on the landscape. Villages where lands were extensively maintained turned out to be mainly characterized by emigration and aging of their inhabitants; such extensification was also significantly correlated with the woody vegetation cover in the 1970s. Five settlement profiles could be distinguished: urbanized, intensified (both comprising only one settlement), extensified, overgrown and forested types of settlements. Most study sites displayed a trend of extensification, with maintained grasslands and fruit trees instead of traditional croplands and much livestock. Also, often areas became overgrown by bushes and vegetation, mainly at edges and on mountain areas of settlement territories, but also centrally within villages overgrown grasslands occur. These processes -along with the increase of fruit trees- caused a shift from rather open to more closed landscapes within settlements.

Public attitudes towards such "rewilding" processes (sensu Bauer et al. 2009) and social-ecological benefits (Navarro and Pereira 2012) should be studied in order to develop policies to cope with the phenomenon of overgrown village territories that occurs in many mountainous regions in Mediterranean Europe.

\section{Authors' contributions}

The first author, AK, designed the research setup and conducted this research. She visited the research area, collected relevant data and she analyzed and interpreted the data. She also drafted the manuscript for this research. She has constantly worked in the research area for 2 months. The second author, VS, permanently lives in the research area, participated in the data collection and shared his scientific knowledge of the research area. The last author, JN, planned the research and together with the third author, VVE, supervised the first author. They also contributed towards developing, editing and finalizing of the manuscript. All authors read and approved the final manuscript.

\section{Author details}

${ }^{1}$ Department of Geography, Ghent University, Ghent, Belgium. ${ }^{2}$ Department of Geography, University of Montenegro, Nikšić, Montenegro.

\section{Acknowledgements}

Our gratitude is directed to all translators who have been helping to communicate with the local inhabitants, Amaury Frankl for his exploratory field visit and Tom Lenaerts for his assistance during the field work itself. We would also like to express many thanks to all interviewees for providing information and hospitality, as well as to Sabine Cnudde for language editing. We acknowledge the constructive comments on an earlier version of this manuscript by two anonymous reviewers.

\section{Competing interests}

The authors declare that they have no competing interests.

Received: 18 July 2015 Accepted: 30 March 2016

Published online: 19 April 2016

\section{References}

Andelić M, Dees M, Pantić D, Borota D, Šljukić B, Čurović M (2012) Status of forest resources of Montenegro. Agricult For 57:39-52

Annys K, Frankl A, Spalević V, Čurović M, Borota D, Nyssen J (2014) Geomorphology of the Durmitor Mountains and surrounding plateau Jezerska Površ (Montenegro). J Maps 10(4):600-611

Antrop M (2000) Background concepts for integrated landscape analysis. Agric Ecosyst Environ 77:17-28

Antrop M (2005) Why landscapes of the past are important for the future. Landsc Urban Plan 70(1-2):21-34

Baldock D, Beaufoy G, Brouwer F, Godeschalk F (1996) Farming at the margins. Abandonment or redeployment of agricultural land in Europe. Institute for European Environmental Policy/Agricultural Economics Research Institute, London/The Hague

Bauer N, Wallner A, Hunziker M (2009) The change of European landscapes: human-nature relationships, public attitudes towards rewilding, and the implications for landscape management in Switzerland. J Environ Manag 90(9):2910-2920 
Bellhouse DR (1981) Area estimation by point-counting techniques. Biometrics 37:303-312

Calo F, Parise M (2006) Evaluating the human disturbance to karst environments in Southern Italy. Acta Carsologica 35:47-56

Chartin C, Bourennane H, Salvador-Blanes S, Hinschberger F, Macaire JJ (2011) Classification and mapping of anthropogenic landforms on cultivated hill slopes using DEMs and soil thickness data: example from the SW Parisian Basin, France. Geomorphology 135:8-20

Čurović Z, Popović S (2014) Typological classification of settlements in the rural hinterland of the bay of Boka Kotorska. Agricult For 60(4):275-289

Dodgshon RA, Olsson EGA (2007) Seasonality in European mountain areas: a study in human ecology. In: Palang H, Printsmann A, Soovali H (eds) Seasonal landscapes. Springer, Dordrecht, pp 85-102

Fagerholm N, Käyhkö N, Ndumbaro F, Khamis M (2012) Community stakeholders' knowledge in landscape assessments - mapping indicators for landscape services. Ecol Ind 18:421-433

Foster-Turley P, Grimes A, Sedej M (2010) Biodiversity analysis update for Montenegro, May 2010. USAID Serbia, Belgrade

Frankl A, Lenaerts T, Radusinović S, Spalević V, Nyssen J (2016) The regional geomorphology of Montenegro mapped using land surface parameters. Zeitschrift für Geomorphologie 60(1):1-14

Fry G (2000) The landscape character of Norway — landscape values today and tomorrow. In: Pedroli B (ed) Landscape, our home. Essays on the culture of the European landscape as a task. Christofoor, Zeist, pp 93-99

Galletta A (2013) Mastering the semi-structured interview and beyond: from research design to analysis and publication. New York University Press, New York

Glavonjić BD, Krajnc N (2013) Wood fuels consumption in households in Montenegro. Therm Sci 17:323-332

Grimes AP, Latif MA, Vujadinovic-Colic J, Buskovic V (2005) Biodiversity assessment update for Serbia and Montenegro. USAID Serbia-Montenegro, Belgrade

Jepsen MR, Kuemmerle T, Erb K, Verburge PH, Müller D, Reenberg A, Haberl H, Vesterager JP, Zhllima E, Krausmann F, Van Eetvelde V, Antrop M, Chromý P, Jančáki V, Pärnj J, Mander U, Björnk I, Terkenli TS, Schistou D, KonkolyGyurómó E, Bondeau A, McDonagh J, Niedertscheider M, Olǵg Nikodemus O, Daugirdas V, Ribokas G, Schmit G, Caspar G, Cassar LF, Conrad E, Austrheim G, Tretvik AM, Ostapowiczxz K, Trzepacz P, Kozak J, Pinto-Correia T, Vadineanu A, Izakovicova A, Kladnik D, Andrič M, Elena-Rosselló R, Pérez-Soba M, Jansson U, Gimmi U, Walz A, Bürgi M, Bryson J, Rounsevell $M$ (2015) Transitions in European land management regimes between 1800 and 2010. Land Use Policy 49:53-64

Klijn J, Vos W (eds) (2000) From landscape ecology to landscape science. Kluwer, London

Kranjc A (2008) History of deforestation and reforestation in the Dinaric Karst. Geogrl Res 47:15-23

LaGro JA (2001) site analysis. Linking program and concept in land planning and design. Wiley, New York
Lazic M, Sekelj L (1997) Privatisation in Yugoslavia (Serbia and Montenegro). Eur-Asia Stud 49:1057-1070

Leech NL, Onwuegbuzie AJ (2007) An array of qualitative data analysis tools: a call for data analysis triangulation. Sch Psychol Q 22:557-584

MacDonald D, Crabtree JR, Wiesinger G, Dax T, Stamou T, Fleury P, Gutierrez Lazpita J, Gibon A (2000) Agricultural abandonment in mountain areas of Europe: environmental consequences and policy response. J Environ Manag 59:47-69

Miller NJ (2005) Serbia and Montenegro. In: Frucht R (ed) Eastern Europe. An introduction to the people, lands, and culture. ABC-CLIO, Santa Barbara, pp 529-581

MONSTAT Statistical Office of Montenegro (2011) Table N4: population by age and sex by settlement. http://www.monstat.org/eng/page. php?id=395\&pageid=57. Accessed 24 Jun 2013

MONSTAT Statistical Office of Montenegro (2011) Table SN1: dwellings by use, i.e. by purpose by settlement. http://www.monstat.org/eng/page. php?id=452\&pageid=57. Accessed 24 Jun 2013

Mottet A, Ladet S, Coqué N, Gibon A (2006) Agricultural land-use change and its drivers in mountain landscapes: a case study in the Pyrenees. Agric Ecosyst Environ 114:296-310

Mugoša R (2008) Spatial plan of Montenegro until 2020. Ministry of Economic Development, Podgorica

Navarro LM, Pereira HM (2012) Rewilding abandoned landscapes in Europe. Ecosystems 15(6):900-912

Neuman WL (2003) Social research methods: qualitative and quantitative approaches. Allyn and Bacon, Boston

Nyssen J, Van den Branden J, Spalević V, Frankl A, Van de Velde L, Čurović M, Billi P (2014) Twentieth century land resilience in Montenegro and consequent hydrological response. Land Degrad Dev 25:336-349

Pausic A, Carni A (2012) Landscape transformation in the low karst plain of Bela krajina (SE Slovenia) over the last 220 years. Acta Geogr Slov-Geogr Zb 52:35-51

Pittaway M (2004) Eastern Europe 1939-2000. Arnold, London

Pond E (2006) Endgame in the Balkans. Regime change, European style. Brookings Institution Press, Washington

Radović M (1981) Savremene društveno-ekonomske promjene u SR Crnoj Gori. In: Ivanović Z (ed) XI Congress of Yugoslav Geographers in Montenegro. Geografsko Društvo SR Crne Gore, Titograd, pp 32-33

Renes $\mathrm{H}$ (2015) Historic landscapes without history? A reconsideration of the concept of traditional landscapes. Rural Landsc Soc Environ Hist 2(1):1-11

Schirpke U, Leitinger G, Tappeiner U, Tasser E (2012) SPA-LUCC: developing land-use/cover scenarios in mountain landscapes. Ecol Inform 12:68-76

Strauss A, Corbin J (1998) Basics of qualitative research: Grounded theory procedures and techniques. Sage, Thousand Oaks

\section{Submit your manuscript to a SpringerOpen ${ }^{\circ}$ journal and benefit from:}

- Convenient online submission

- Rigorous peer review

- Immediate publication on acceptance

- Open access: articles freely available online

- High visibility within the field

- Retaining the copyright to your article

Submit your next manuscript at $\boldsymbol{\nabla}$ springeropen.com 